\title{
СЛОВОТВІРНА МОРФОНОЛОГІЯ ВІДСУБСТАНТИВНИХ СУФІКСАЛЬНИХ ДІЕСЛІВ ІНШОМОВНОГО ПОХОДЖЕННЯ
}

Зюзькіна Г. М. Словотвірна морфонологія відсубстантивних суфіксальних дієслів іншомовного походження.

У статті розглядаються морфонологічні особливості словотвірних морфем та дається характеристика морфонологічних явищ, зафіксованих при словотворенні відсубстантивних суфіксальних дієслів іншомовного походження, складаються морфонологічні моделі і морфонологічні класи зазначених дериватів.

Ключові слова: похідні дієслова, морфонологічні явища, морфонологічні моделі, морфонологічні класи.

Зюзькина Г. М. Словообразовательная морфонология отсубстантивных суффиксальных глаголов иноязычного происхождения.

В статье рассматриваются морфонологические особенности словообразовательных морфем и дается характеристика морфонологических явлений, зафиксированных при словообразовании отсубстантивных суффиксальних глаголов иноязычного происхождения, составляються морфонологические модели и морфонологические классы указанных дериватов.

Ключевые слова: производные глаголы, морфонологические явления, морфонологические модели, морфонологические классы. nouns.

Ziuzkina H. M. The word-forming morphonology of borrowed verbs derived from

The article deals with the process of word-forming of borrowed verbs. The morphonological features of word-formative morphemes are described. The analysis of morphonological phenomena is given. The morphonological models and morphonological classes of derived verbs are established.

Key words: derived verbs, morphonological phenomena, morphonological models, morphonological classes. 
Дієслово є найважливішою лексичною одиницею будь-якої мови. Воно, за твердженням В. Виноградова, належить до найскладніших i найбільш містких граматичних категорій; дієслово найбільш конструктивне в порівнянні зі всіма іншими категоріями частин мови, дієслівні конструкції мають вирішальний вплив на іменні словосполучення і речення [2, с. 349].

До того ж, як відзначає Т. Попова, дієслово за кількістю об'єднуваних цією частиною мови слів поступається лише іменникам, воно володіє значним потенціалом деривата і виступає основною словотворчою силою будь-якого словотвірного гнізда, тим самим значно впливаючи на всю дериваційну систему мови [5, с. 3-4].

Дієслова іншомовного походження становлять органічний компонент дериваційної системи української мови, тому виявлені у процесі дослідження морфонологічні особливості творення зазначених дериватів можуть слугувати основою для ширших узагальнень особливостей та закономірностей словотвірної адаптації запозичень до системи української мови.

Морфонологічні явища та закономірності словотворення розглядалися у працях Р. Аванесова, С. Бернштейна, Я. Босака, С. Бромлей, Т. Булигіної, Д. Ворта, В. Дресслера, О. Земської, Н. Ільїної, О. Ісаченка, Л. Лопатіна, В. Касевича, К. Ковалик, О. Кубрякової, Р. Лясковського, Ю. Панкраца, М. Панова, Т. Попової, Е. Станкевича, С. Толстої, М. Трубецького, Г. Улашина, І. Улуханова, В. Чурганової.

В україністиці ж проблеми морфонології протягом тривалого часу порушувалися лише у зв'язку з вивченням явищ словозміни та формо- $\mathrm{i}$ словотворення в працях Л. Гумецької, А. Грищенка, В. Горпинич, К. Городенської, Т. Грязнухіної, М. Федурко, І. Ковалика, Н. Клименко, Л. Полюги, Л. Родніної, 3. Сікорської.

У зв'язку з цим виникла необхідність системного дослідження морфонологічних трансформацій, що супроводжують процес словотворення відсубстантивних суфіксальних дієслів іншомовного походження в сучасній українській мові.

Метою статті є дослідження морфонологічних закономірностей словотворення дієслів від основ іншомовного походження. Досягнення поставленої мети передбачає розв'язання таких завдань: проаналізувати морфонологічні ознаки словотвірних морфем; з'ясувати морфонологічні зміни і встановити морфонологічні явища при словотворенні похідних зазначеного типу; описати морфонологічну структуру похідних дієслів, склавши морфонологічні моделі дериватів; скласти загальні 


\section{СТРУКТУРА І СЕМАНТИКА МОВНИХ ОДИНИЦЬ}

морфонологічні класи похідних дієслів іншомовного походження як свідчення певного ступеня їх адаптації на грунті української мови.

За структурою дієслова іншомовного походження представлені непохідними та похідними основами. До непохідних належать ті, які потрапили до лексичної системи української мови безпосередньо з мовиджерела або через посередництво якоїсь мови і не встановили на грунті української мови словотвірні зв'язки з іменними основами, які виділяли б їх структурно і мотивували семантично, тобто ті дієслова іншомовного походження, передсуфіксальна частина яких не вживається самостійно в сучасній українській мові: девальвувати, декларувати, ратифікувати. Статус похідних мають ті дієслова, які утворилися від іншомовних іменних основ - іменникових та прикметникових - на грунті української мови або встановили тут словотвірні зв'язки 3 іншомовними іменними основами. Визначальним способом творення таких дієслів $є$ суфіксальний: приватизувати, нормалізувати, субсидувати, лобіювати. Обмежено використано префіксально-суфіксальний спосіб (збюрократити, з'яничарити) та складання (самоідентифікуватися) [4, с. 3].

Отже об’єктом аналізу запропонованого дослідження вибрано відсубстантивні дієслова як ті, що становлять найчисленнішу групу серед суфіксальних дієслів з іншомовними основами. В їх утворенні беруть участь наступні суфікси: -ува- : тампон - тампонувати, гранула - гранулювати, зонд - зондувати, деталь - деталювати; -ирува- (-ірува-): мари мариирувати, фари - фаричрувати; -изува- (-ізува-): ідеал - ідеалізувати, стиль - стилізувати, романтизм - романтизувати; -ифікува- (-іфікува-): клас - класифікувати, мумія - муміфікувати, -ствува-: філософія філософствувати, прожектер - прожектерствувати, бригадир бригадирствувати; -и-: фасон - фасонити, рикошет - рикошетити, каламбур - каламбурити; -нича-: секрет - секретничати, саботаж саботажничати.

На думку російського мовознавця Н. Алілової, для «сучасної системи не має значення, чи $\epsilon$ дане дієслово за походженням запозиченим, чи воно утворено на слов'янському грунті. Важливо лише, чи мотивує його «первинний» іменник цілком, основа іменника або воно знаходиться з іменником у відношеннях взаємної мотивації» [1, с. 171].

«Для більшості відсубстантивних дієслів 3 іншомовними основами характерна прозорість виділення мотивуючої основи, регулярність співвідношень дієслова та мотивуючого іменника або дієслова та іменника, що знаходиться 3 дієсловом у відношеннях взаємної мотивації» [1, с. 175]. Слід зауважити, що новоутворення виявляють прогресуючу тенденцію до 
такого чіткого виділення твірної основи: анонс - анонсувати, алкіл алкілувати, теза - тезувати. Як зазначає К. Городенська, морфемна структура таких дієслівних основ найбільш прозора, оскільки іменний корінь поєднується з дієслівним суфіксом без будь-яких морфонологічних змін [3, с. 31]. Але деякі дісслова іншомовного походження у співвідношенні з твірними основами мають у своїй структурі регулярні або нерегулярні зміни на межі основ, що зумовлені головним чином різними іншомовними прототипами або різночасовими запозиченнями.

Залежно від того, яких саме змін зазнає фонемна структура морфем (чи основ) під час словотворення вербальних дериватів за допомогою суфіксів -ува-, -ирува-, -изува- (-ізува-), -ифікува-(-іфікува-), -ствува-, -нича-, -и- виявлено такі типи морфонологічних явищ: 1) альтернація фонем; 2) усічення; 3) нарощення; 4) модифікація наголосу. Якісні характеристики цих явищ визначаються як внутрішніми особливостями їх формування, так i властивостями того дериваційного процесу, в ході якого вони відбуваються.

Альтернацію фонем при словотворенні вербальних похідних іншомовного походження класифікуємо за місцем маніфестації, як ту, що відбувається на морфемному шві, а саме в морфах твірної основи:

a) чергування приголосних фонем $\boldsymbol{C}-\boldsymbol{C}$ : музика - музичити, параліч - паралізувати, ерозія - еродувати, діагноз - діагностувати;

б) палаталізація приголосних фонем $\boldsymbol{C}-\boldsymbol{C}^{\prime}$ : ацетил - ацетилювати, тремоло - тремолювати, алгоритм - алгоритмізувати;

c) депалаталізація приголосних фонем $\boldsymbol{C}^{\prime}-\boldsymbol{C}$ : каніфоль каніфолити, комісія - комісувати, теорія - теоретизувати; і ту, що відбувається в кореневих морфах твірної основи: банчер - банчирувати, валець - вальцювати (виключно чергування голосних фонем $\mathbf{V}-\mathbf{V}, \mathbf{V}-\boldsymbol{\emptyset}$ ).

Слід зазначити, що кожне окреме чергування відзначається неоднаковою регулярністю навіть у межах словотворення вербальних похідних іншомовного походження. Пояснюється це характером мотивуючих іменникових основ, зокрема їх кінцевою фонемною структурою, а також залежить від певного дієслівного суфікса, з яким поєднується основа.

Явище усічення можна класифікувати за фонемним комплексом на три групи: 1) усічення голосних фонем (Уv): декольте - декольтувати, плаке - плакувати, протеже - протегувати; 2) усічення приголосних фонем (Ус): конкурс - конкурувати, етикетка - етикетувати; 3) усічення фонемних сполук (Уf): пацифізм - пацифікувати, бюрократія - бюрократизувати, архаӥка - архайзувати.

Аналогічно можна класифікувати i явище нарощення:

(С) Г. М. Зюзькіна, 2015. 
1) нарощення голосних фонем (Hv): при словотворенні вербальних дериватів 3 іншомовними основами не зафіксовано; 2) нарощення приголосних фонем (Hc): крокі - крокіювати, тату - татуювати; 3) нарощення фонемних сполук (Нf): аксіома - аксіоматизувати, Америка-американізувати, жест-жестикулювати.

Коливання наголосу в запозичених словах неминуче: воно свідчить про те, що дієслова іншомовного походження взаємодіють $з$ українською лексикою та поступово асимілюються нею. Наголос у суфіксальних вербальних похідних від іншомовних основ виступає морфонологічним засобом словотворення дериватів, тому поняття наголосу розглядаємо через поняття акцентної позиції. Аналіз зазначених дериватів дає можливість встановити дві акцентні позиції: 1) нерухомий наголос (1А): епігра́ма - епігра́мити, сабота́ж-сабота́жничати, 2) наголошений похідний суфікс (4A): бо́мба-бомби́ ти, ста́ рm-стартува́ ти.

У сучасній українській мові найпродуктивнішим засобом формування відсубстантивних суфіксальних дієслів від основ іншомовного походження виступає суфікс -ува- (619 дериватів). Виявлено 14 морфонологічних моделей, характерних для основ зазначених дериватів на -yва-: M1 (516): Io(4A) + -yва-: кроке́m крокетува́ти, телефо́н - телефонува́ти, гі́nс - гіпсува́ти, ата́каатакува́ ти, М2 (25): $\boldsymbol{I o}\left(\boldsymbol{Y} \boldsymbol{f}, \boldsymbol{C}^{\prime}-\boldsymbol{C}, \mathbf{4 A}\right)+$-ува-: анестезія - анестезува́ ти, реце́ нзія-рецензува́ ти, філосо́ фія філософува́ ти, М3 (16): $\boldsymbol{I o}\left(\boldsymbol{C}-\boldsymbol{C}^{\prime}, 4 \boldsymbol{A}\right)$ + -ува-: ацетил- ацетилюва́ти, протоко́л- протоколюва́ти, шахта́ шахтарюва́ ти M4 (16): $\boldsymbol{I o}(\boldsymbol{Y} \boldsymbol{f}, \boldsymbol{H} \boldsymbol{f}, \boldsymbol{4 A})+$-ува-: опози́ цुія-опозиціонува́ ти, селе́кція - селекціонува́ ти, функція - функціонува́ ти, М5 (8): Io(Уf, $4 \boldsymbol{A})+$ -ува-: циита́ та - цитуува́ ти, шварто́ - швартува́ ти, М6 (7): Io (Уv, 4A) + -ува-: резюме́ - резюмува́ ти, плаке́- плакува́ ти, М7 (6): Io $(\boldsymbol{У} \boldsymbol{f}, \boldsymbol{C}-\boldsymbol{C}, \mathbf{4 A})+$ -ува-: суспе́нзія - суспендува́ти, прое́киія - проектува́ти М8 (5): $\boldsymbol{I o}\left(\boldsymbol{y} \boldsymbol{v}, \boldsymbol{C}^{\prime}-\boldsymbol{C}, \mathbf{4 A}\right)+$-yвa-: травесті - травестува́mи, хі́ni- хіпува́ти, M9 (5): Io $(\boldsymbol{C}-\boldsymbol{C}, 4 \boldsymbol{A})$ + -ува-: рефле́ кс - рефлектува́ти, риме́ са риметува́ти, M10 (4): Io(V-V/V-Ø, 4A) + -ува-: де́мпфер демпфірува́ ти, ша́бер- шабрува́ти, M11 (4): Io(Hc, 4A) + -ува-: лоб білобіюва́ ти, табу' - табуюва́ти $\mathrm{M} 12$ (3): $\boldsymbol{I o}\left(\mathbf{Y} \boldsymbol{v} / \boldsymbol{f}, \boldsymbol{C}-\boldsymbol{C}^{\prime}, \mathbf{4 A}\right)+$ - yва-: постула́ m- постулюва́ ти, тре́ моло- тремолюва́ ти, М13 (2): Io(Ус, 4A) + -ува-: ко́ нкурс - конкурува́ти, етике́тка - етикетува́ти M14 (2): $\boldsymbol{I o}(\boldsymbol{H} \boldsymbol{f}, 4 \boldsymbol{A})+$-ува-: ма́ триия-матриціюва́ ти, же́ ст-жестикулюва́ ти.

У сучасній українській мові не менш продуктивним засобом формування дієслів від основ іншомовного походження виступає суфікс -изува- (-ізува-) (133 деривати). Виявлено 11 морфонологічних моделей, 
характерних для відсубстантивних дієслів іншомовного походження на -изува- (-ізува-): М1 (36): Іо $\left(\boldsymbol{C}-\boldsymbol{C}^{\prime}, \mathbf{4 A}\right)+$-ізува-: символ-символізува́ ти, желатин - желатинізува́ти М2 (31): $\boldsymbol{I o}(\boldsymbol{Y} \boldsymbol{f}, \mathbf{4 A})$ + -ізува-: геройзм героїзува́ти, етимоло́ гія- етимологізува́ти М3 (30): Іо(4A) + -изува-: арома́m - ароматизува́ти, мета́фора - метафоризува́ти, M4 (7): Iо(4A) + -ізува-: алкоголь-алкоголізува ти, вакуо ля-вакуолізува́ ти М5 (7): $\boldsymbol{I o}\left(\boldsymbol{Y} \boldsymbol{f}, \boldsymbol{C}^{\prime}-\boldsymbol{C}, \mathbf{4 A}\right)+$-изува-: герба́ рій - гербаризува́ти, демокра́тія демократизува́ ти, M6 (5): $\boldsymbol{I o}(\boldsymbol{H} \boldsymbol{f}, \mathbf{4 A})+$-изува-: фле́ гма- флегматизува́ ти, дра́ма - драматизува́ти, М7 (5): Io(Уf, 4A) + -изува-: фетиши зм фетишизува́ ти, белетри́ зм- белетризуватти, М8 (4): $\boldsymbol{I o}\left(\boldsymbol{У} \boldsymbol{f}, \boldsymbol{C}-\boldsymbol{C}^{\prime}, 4 \boldsymbol{A}\right)+$ -ізува-: о птимум - оптимізува́ти, ма́ксимум - максимізува́ти М9 (3): $\boldsymbol{I o}(\boldsymbol{H} \boldsymbol{f}, 4 \boldsymbol{A})$ + -ізува-: євро́ па - європеїзува́ ти, а́лгебра - алгебраӥзува́ти, M10 (3): $\boldsymbol{I o}(\boldsymbol{C}-\boldsymbol{C}, \mathbf{4 A})+$-изува-: гіпноз - гіпнотизува́ ти, ха́ ос-хаотизува́ти, M11 (2): $\boldsymbol{I o}(\boldsymbol{Y} \boldsymbol{f}, \boldsymbol{H f}, \boldsymbol{4 A})$ + -ізува-: коме́ риія-комерціалізува́ ти, револю́ цуіяреволючіонізувати.

Словотворення відсубстантивних дієслів від основ іншомовного походження 3 питомим українським суфіксом -и- (53 деривати) репрезентують 5 морфонологічних моделей: M1 (44): Io(1A) + -u-: партиза́ н - партиза́ нити, магні́m - магнітити; М2 (4): Io(4A) + -и-:

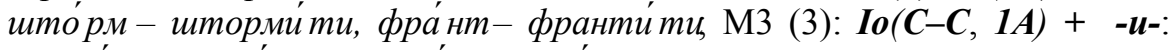
батра́к- батра́ чити, музи́ ка- музи́ чити, М4 (1): Io $\left(\boldsymbol{У} \boldsymbol{f}, \boldsymbol{C}^{\prime}-\boldsymbol{C}, \boldsymbol{1 A}\right)+-\boldsymbol{u - :}$ еконо́ мія - еконо́ мити, М5 (1): Io $\left(\boldsymbol{C}^{\prime}-\boldsymbol{C}, \mathbf{1 A}\right)+$-и-: каніфо́ ль-каніфо́ лити.

Зафіксовано досить незначну кількість суфіксальних дієслів іншомовного походження словотвірних типів на -ирува- (-ірува-) (6 дериватів), -ифікува- (-іфікува-) (9 дериватів) і -ствува- (5 дериватів), що дає можливість скласти 3 морфонологічні моделі дериватів на -ирува-: M1: Iо (4A) + -ирува-: а́кm - актирува́ти, фа́рш - фарширува́ти, M2: Io $(\mathbf{Y} \boldsymbol{v}, 4 \boldsymbol{A})$ + -ирува-: плісе́ - плісирува́ ти, драже́ - дражирува́ти, M3: Iо $\left(\boldsymbol{C}-\boldsymbol{C}^{\prime}, \mathbf{4 A}\right)+$-ірува-: піке́ - пікірува́ти, дра́га - драгірува́ти, 3 моделі дериватів на -ифікува-(-іфікува-): М1: Io(4A) + -ифікува-: тре́ сттрестифікува́ ти, га́ з- газифікува́ ти, М2: $\boldsymbol{I o}(\boldsymbol{Y} \boldsymbol{f}, 4 \boldsymbol{A})+$-ифікува-: ко декскодифікува́ ти, пла́ стика- пластифікува́ ти, М3: $\mathbf{I o}(\mathbf{Y f}, 4 \boldsymbol{A})+$-іфікува-: му'мія-муміфрікува́ ти, амо́ ній-амоніфікува́ти, і 1 модель дериватів на -ствува-: М1: Io(1A) + -ствува-: фаши ст - фаши ствувати, патріо́ mпатріо тствувати.

Для вербальних дериватів іншомовного походження словотвірного типу на -ича- і -нича- характерні така модель: $\boldsymbol{I o}(\boldsymbol{1 A})+$-нича-: ловела́ ловела́ сничати, авантю́ ра- авантю́ рничати.

На підставі проведеного аналізу стає можливим узагальнення всіх () Г. М. Зюзькіна, 2015. 
морфонологічних явищ, які супроводжують дериваційний процес суфіксальних дієслів іншомовного походження та встановлення морфонологічних класів зазначених дериватів.

Словотворення відсубстантивних суфіксальних дієслів іншомовного походження характеризується наявністю таких морфонологічних класів дериватів: МК-о - «нульовий» (відсутність морфонологічних трансформацій): ІІо(-)+-нича-, -ствува-, -и- (44 деривати); МК-1 «елементарний» (одна морфонологічна трансформація): $\boldsymbol{I o}(\boldsymbol{M H} / \boldsymbol{A \Phi})+-\boldsymbol{u}$, -ува-, -ирува- (-ірува-), -изува- (-ізува-), -ифікува- (-іфікува-) (568 дериватів); МК-2 - «комплексний, двоплановий» (комплекс 3 двох морфонологічних

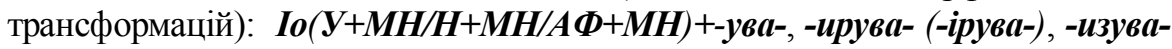
(-ізува-), -ифікува- (-іфікува-) (150 дериватів); МК-3 - «комплексний триплановий» (комплекс із трьох морфонологічних трансформацій): Іо $(\boldsymbol{A \Phi}+\boldsymbol{У}+\boldsymbol{M H} / \mathbf{Y}+\boldsymbol{H}+\boldsymbol{M H})+$-уува-, -изува- (-ізува-) (56 дериватів).

Отже, проаналізувавши морфонологічні особливості словотворення суфіксальних вербальних похідних іншомовного походження, ми дійшли висновків, що дослідження зазначених особливостей дає змогу вивчити процес взаємопристосування мотивуючої іменникової основи та дериваційного форманта, для яких характерні такі види морфонологічних явищ, як модифікація наголосу, усічення, нарощення, чергування.

Найпоширенішим морфонологічними модифікаціями при словотворенні вербативів від іншомовних основ є модифікація наголосу та усічення фонем. Найпродуктивнішим морфонологічним класом відсубстантивних суфіксальних вербативів іншомовного походження $є$ «комплексний, двоплановий» - дериваційний процес супроводжується комплексом 3 двох морфонологічних трансформацій (усічення фіналі твірної основи і модифікації наголосу). Аналіз морфонологічних моделей і встановлення морфонологічних класів дієслів іншомовного походження, дає змогу описати морфонологічну структуру дериватів, дослідити механізм зазначених морфонологічних модифікацій i відповідно виразніше окреслити процес словотвірної та морфонологічної адаптації іменників іншомовного походження.

Перспективу подальшого дослідження убачаємо у виробленні принципів опису морфонологічних класів дериватів іншомовного походження та систематизуванні основних морфонологічних характеристик дериваційного процесу від основ іншомовного походження.

М - морфонологічна модель;

\section{Умовні скорочення}


МК - морфонологічний клас;

МН - модифікація наголосу;

АФ - альтернація фонем;

А - акцентна позиція;

$\mathrm{V}$ - будь-яка голосна;

$\mathrm{C}$ - будь-яка приголосна;

У - усічення;

Н - накладання;

Іо - іменникова основа.

\section{Література}

1. Авилова Н. С. Слова интернационального происхождения в русском литературном языке нового времени / Н. С. Авилова. - М. : Наука, 1967. - 245 с.

2. Виноградов В. В. Русский язык. Грамматическое учение о слове / В. В. Виноградов. - М., 2001. - 718 с.

3. Городенська К. Г. Словотвірна структура слова (відіменні деривати) / К. Г. Городенська, М. В. Кравченко. - К. : Наукова думка, 1981. - 198 с.

4. Навальна М. І. Дієслівна лексика соціально-економічної сфери (на матеріалі мови засобів масової інформації кінця XX ст.) : автореф. дис. ... канд. філол. наук / М. І. Навальна. - К., 2002. - 18 с.

5. Попова Т. В. Русские непроизводные глаголы : морфемная структура и деривационные особенности / Т. В. Попова. - Екатеринбург, 1996. - 119 с.

Стаття надійшла до редакиії 30.06 .2015 p. 